\title{
How commodity prices and technical development has influenced exploration strategies: a case study from Sweden
}

\author{
Pär Weihed ${ }^{1}$ (D)
}

Received: 2 October 2021 / Accepted: 16 January 2022 / Published online: 31 January 2022

(c) The Author(s) 2022

\begin{abstract}
In Sweden, mining of metallic mineral resources goes back at least 1000 years, possibly much longer. This paper reviews the development of exploration over the past 500 years and discusses exploration based on 1) demand and price, 2) technical development, and 3) legislation. Without doubt, exploration efforts have been driven by an early demand, especially from the Swedish crown and well-known mines such as Falun copper mine and Sala silver mine sustained the Swedish crown and financed several wars during the seventeenth and eighteenth centuries for several centuries. The fluctuation in metal prices, basically a function of demand, due to technical development and industrialization, has been an important driver for the focus of exploration over the last 100 years, and even more so during the last 50 years when exploration, besides base metals and iron, has focussed on more critical raw materials for the energy transition and green technology. The technical development has also meant that new methods have become available for exploration, not the least deep exploration methods and Swedish innovations have played a major role in drilling technology, geophysical instrument development and other areas. This is discussed based on development in drilling technology, geological, geophysical and geochemical methods. Finally, a review of the how the mining legislation has changed over the last 500 years is provided where this is placed in the context of how it has influenced private investment in exploration and what role the Swedish state has played.
\end{abstract}

Keywords Exploration $\cdot$ Sweden $\cdot$ Commodity prices $\cdot$ Technical development

JEL codes $\mathrm{L} 10 \cdot \mathrm{L} 61 \cdot \mathrm{L} 72 \cdot \mathrm{O} 13 \cdot \mathrm{O} 31 \cdot \mathrm{P} 48 \cdot \mathrm{Q} 02 \cdot \mathrm{Q} 30$

\section{Introduction}

Over the past 100 years, exploration strategies has developed in parallel with the growth of the modern society and industrialization as we know it today. Exploration strategies have been adopted to supply the society with metals with a fairly short commodity cycle focus and in this paper we review strategies developed in Sweden and discuss how the focus have shifted on both commodity types, i.e. what metals are we looking for, and deposit styles, i.e. high grade/low tonnage vs. low grade/high tonnage.

In Sweden, exploration and mining of metallic mineral deposits goes back at least 1000 years (cf. Tegengren 1924). Well-known mines such as Falun copper mine and Sala

Pär Weihed

par.weihed@1tu.se

1 Luleå University of Technology Sweden, SE-971 97 Luleå, Sweden silver mine sustained the Swedish crown for several centuries. Exploration strategies before the industrial revolution in the mid 1800-hundreds were not sophisticated and focused on maximizing income to the Swedish state from mining iron, base and precious metals from outcropping mineral deposits primarily in the Bergslagen region. With the onset of the industrial revolution the demand for these and other commodities grow, exploration intensified and many western countries, including Sweden, established geological survey organisations that were responsible for identifying the mineral potential of the country.

In Sweden, this led to an intensified exploration for iron and copper in the late nineteenth century and early twentieth century. The global gold-rush at the same time also led to intensified exploration strategies for precious metals in Sweden. This also led to the establishment of the Boliden company, which is since then, the largest privately-owned mining and exploration company in Sweden. The demand for these commodities continued to be high during the world 
war II, and the high demand for these metals continued to be strong in the decades after the world war II. In Sweden, this led to intensified exploration strategies for iron, primarily led by the Swedish state, and for copper, primarily led by the Boliden company. In the 1970s, the price for copper increased and mining of low-grade high tonnage deposits increased dramatically world-wide. In Sweden the strategy of Boliden, who until then had mining high grade, so called volcanogenic massive sulphide deposits (VMS) in the Bergslagen area and the Skellefte district, now expanded their exploration programme to lower grade deposits and in 1967 the low-grade $\mathrm{Cu}$-deposit Aitik was put in production. Meanwhile the state, through the Geological Survey and LKAB invested heavily in iron ore exploration, mainly in the northern part of Sweden. Many new deposits were found, and trial mining of several deposits took place and the mines in Kiirunavaara and Malmberget were extended.

In the 1980s and 1990s, a new boom of precious metal exploration started, based on the upswing of the price of gold and until today many of the junior exploration companies are focused on gold.

In the last decade, a high demand for called critical raw materials, such as REE, Li, Co a.o. important for the new green technology has mean that many junior exploration companies have shifted their strategies towards these commodities.

\section{Development of Swedish mining industry and early exploration}

More organised mining activities in Sweden dates back to at least the mid-thirteenth century. The oldest preserved document that confirms that mining on an industrial scale dates back to 1288 (cf. Tegengren 1924) where the bishop of Västerås changed the diocese's share in the Falu copper mine in the Bergslagen region, central Sweden. However in a recent study by Bindler et al. (2017) it is suggested, based on geochemical studies of lake sediments from the Garpenberg area that "a clear pattern of human disturbance connected with the ore body bordering the lake" as early as 375-175 $\mathrm{BC}$ and from $400 \mathrm{BC}$ and onwards a permanent increase of copper and lead was identified in the sediments by Bindler et al. (2017), who therefore suggested that the results push back the evidence for early ore mining in Sweden from the Middle Ages to the pre-Roman Iron Age.

The early records also include documented mining activities in the early fourteenth century at Garpenberg (still in operation) for copper and Östra Silvberg for silver. The focus for these early mining activities was the Bergslagen region, which today still constitutes one of three major mining districts in Sweden, together with the Skellefte district and the Norrbotten region, both in the northern part of the country.
Although there are few records of early exploration activities it is clear that the Kings Gustav Vasa and his son King Karl IX had a strong interest in developing the Swedish mining in the second half of the sixteenth century. The latter also employed and sent out so called ore searchers also into the far north of Sweden which was largely unmapped. This can be seen as the first organised exploration efforts in Sweden.

In the next century, 1630, the king Gustav II Adolf established an organisation "Bergsöverstyrelsen" in Swedish, later to become "Bergskollegium", so that the state could better control and organize a systematic search for new ore deposits. This organisation also employed prospectors "malmletare" that reported to the different state employed mine inspectors "Bergmästare" whose job was to supervise the mining operations within his jurisdiction on behalf of the government. Interestingly, this organisation with government employed ore searchers was in operation until 1812 in most of the country, while in the north the system was kept until 1853. Five years later, in 1858, the Geological Survey of Sweden was established with a primary aim to establish a firm understanding of the geological conditions in Sweden in general and in particular to document and describe the potential for mineral extraction in Sweden.

While mining activities were developed early in the Bergslagen region, the onset of the search for ore in the northern part of the country can be said to have started with the exploitation, which started in 1635, of the silver occurrence in Nasafäll in the Lapland mountains. This discovery on the far north of Sweden triggered intensified exploration in this largely unexplored part of the country. In 1644 the Svappavaara copper deposit (e.g. Gruvberget) was discovered together with other minor occurrences.

In the eighteenth century, the first gold deposits of any significance we discovered and mined, Ädelfors in south central Sweden was discovered in 1738 and in the Falu copper mine gold was mined from 1790. During the nineteenth century, zinc-lead deposits were discovered in Bergslagen, in particular the Åmmeberg zinc deposit (Zinkgruvan) which was put in production in 1857.

In the early twentieth century, the use of sulfuric acid in the processing of pulp triggered reopening of several sulphide-rich mines in Sweden. However, the real boom in what can be defined as modern exploration was the discovery of the massive sulphides in the Kristineberg area in 1918 in the westerns part of what was later to be named the Skellefte District in the northern part of Sweden.

\section{Economic wealth}

The mines economic and political importance grew all the time, mostly during the 15 th and 16 th centuries to culminate in the seventeenth century. During the latter part of the sixteenth century, new rich ore deposits were discovered. 
Around 1650, 3,000 tonnes of raw copper were produced from the mined ore in Sweden, and occasionally the rock accounted for two thirds of world production. The income from Kopparberget was a prerequisite for Sweden to be able to establish itself as a great power in Europe. Copper was the country's most important export product and the mine greatly strengthened the country's finances, which made it possible to purchase ships and equipment for the wars that were fought. Copper plates sold to the countries of Europe came to cover the roofs of churches, castles and palaces.

\section{0 years of exploration in Sweden}

The reopening of global trade after the first world war led to a decline in copper prices (Fig. 1), while precious metals, such as gold saw a rise in price (Fig. 2). In many ways this period was the start of modern exploration in Sweden. While the Bergslagen region had been extensively explored, albeit without any modern methods, the onset of iron ore mining in the northern part of Sweden two decades earlier and the major discoveries of base and precious metals in the Skellefte district were both catalysts for a rapid technical development of exploration methods including new geophysical and geochemical inventions together with improved drilling technology. The competition between the state-controlled exploration and domestic private enterprises (the Boliden company) can be said to have characterized exploration for seven decades, until the new mining legislation was put into place in 1991 (Minerallagen 1991:45). Especially the update in 1993 where the Crown share of any mineral extraction was taken away was the start of a new era in exploration in Sweden since state controlled exploration has ceased
Fig. 1 Real copper price 1850-2016 modified from Winton.com (https://www.winton. com/longer-view/copper-botto med-booms-and-busts)
Fig. 2 Gold price over the last 100 years. Modified from Macrotrends (https://www.macro trends.net/1333/historical-goldprices-100-year-chart)
Real Copper Prices (1850-2016)

1000
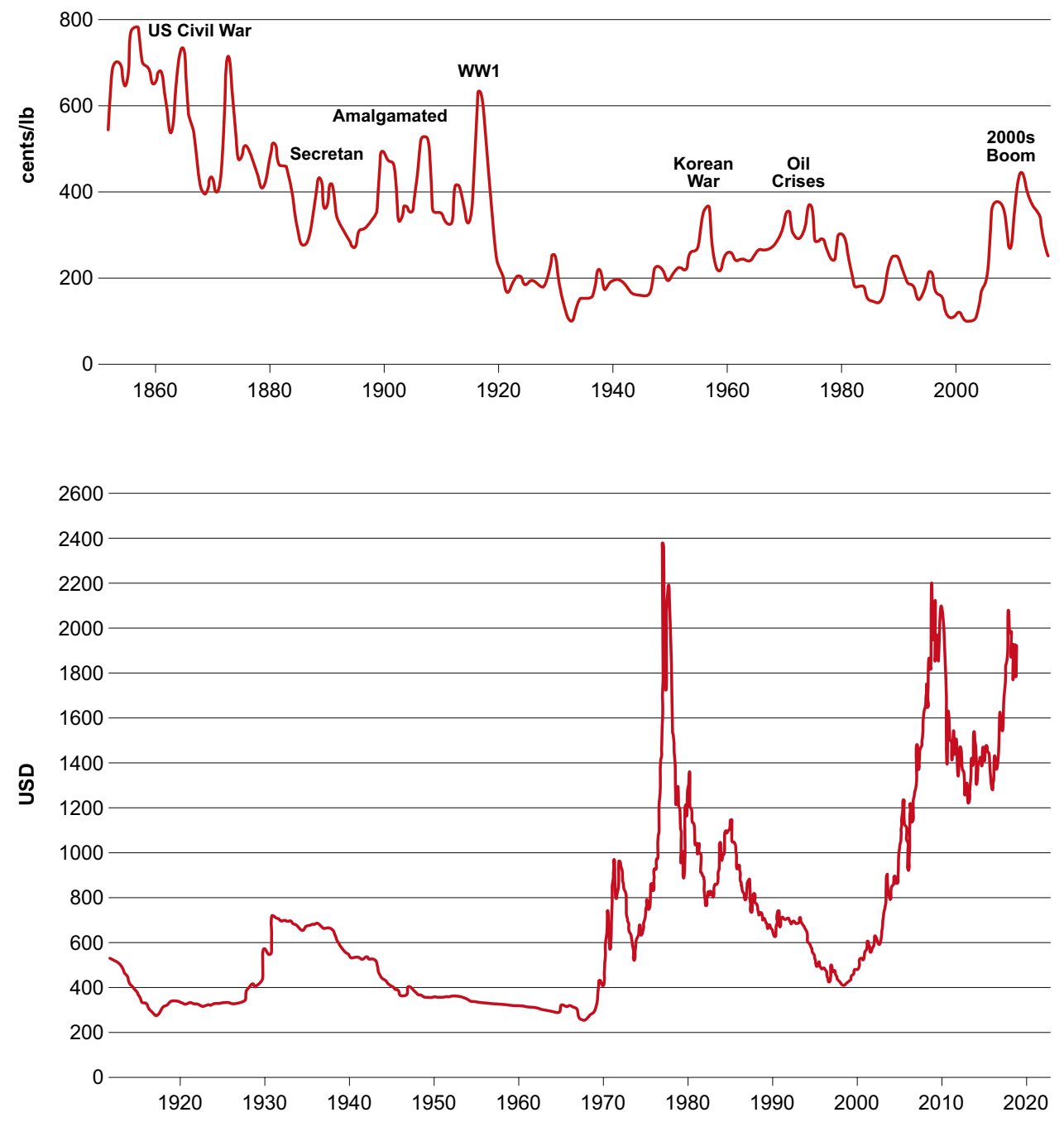
with the closing down of both the Board of State Mining Property (NSG) that commissioned state exploration and the Swedish Geological Company SGAB, that to a large extent executed the state exploration and the fact that now many major and junior exploration companies entered the Swedish stage.

\section{Market and commodities}

Early exploration in Sweden, before the industrial revolution in the mid-nineteenth century was very much driven by the Crown to supply the kingdom of Sweden with metals necessary to $r$ support warfare or to produce coins, and to a large extent finance the crown and warfare. Sweden had during the sixteenth and seventeenth century a dominant global position in the production of copper (Falun mine) and silver (Sala mine) and early prospectors sought for metals such as copper, iron and to some extent silver. The industrial revolution and later the electrification of the western society further strengthened the need for infrastructure metals such as iron and copper, and later also other base metals such as lead and zinc. While precious metals had always played a large role not only as jewellery, but also to secure wealth and when bills (paper money) were introduced in the global economy, it typically was redeemable for gold coin or bullion. These market conditions have over the years controlled what commodities prospectors or exploration companies have looked for.

\section{Commodities}

As stated above, exploration in Sweden has until the last hundred years been focussed on iron, copper and precious metals. In the twentieth century, when utilization of other metals in the industrial development of the society broadened, also exploration for other metals occurred in Sweden.

In the Skellefte district the discovery of the massive sulphide deposits in the early twentieth century (i.e. Kristineberg mine in 1917) led to an increase in the production of base metals such lead and zinc. The Boliden deposits in 1924 , led to intensified exploration for precious metals, primarily in the Skellefte district, both by the state (the Geological Survey) and private interests. During the 1980ies and thereafter, especially due to the changed mining act, there has been a renewed interest for gold exploration in Sweden.

Tungsten resistance to high temperatures, its hardness and density, and its strengthening of alloys made it an important raw material for the arms industry during the world war II and later tungsten carbide became important constituent in cutting tools. Exploration for tungsten, and also molybdenite and tin, was carried out in Sweden after world war
II and especially in the 1970ies and 1980ies. The Ysjöberg mine, originally mined for copper, was producing tungsten between 1935 and 1963, and between 1972 and 1989 when mining stopped due to a low price of tungsten, in turn due to a huge production increase in China.

The development of the nuclear industry after world war II and the development of Swedish nuclear power (first commercial nuclear power plant opened in 1972 in Oskarshamn), also led to intensified exploration for uranium and thorium in Sweden. Especially during the 1970s, there was relatively extensive exploration for uranium both from alumn shales and other type of deposits (cf. Bergverksstatistik 2003). Several Swedish mining companies and the state via the Board of State Mining Property (NSG) participated in this exploration. In a national referendum in 1980, it was decided not to expand nuclear power in Sweden and in spite of the fact that Sweden over the years since the introduction has produced a large share of its electricity from nuclear power, no real mining of uranium has occurred even if exploration has led to the discovery of many substantial deposits. With the referendum, exploration for uranium basically stopped in Sweden.

In the last decade, the new high-tech industry and the electrification of the society led to a shift in exploration towards commodities such as rare earth elements, lithium and cobalt in Sweden. Exploration has identified several interesting deposits, but so far, no mining has occurred. The Norra Kärr deposits in south central Sweden is a good example of the current situation in Sweden. This deposit contains high grades of heavy rare earth element, where there is a high demand, but due to protests and appeals of mining concessions there is still no permit to mine this deposit (se legislation below).

Although minor occurrences of nickel were known and had been mined, active exploration for nickel commenced during world war II, when also the Lainijaur deposit was mined between 1940 and 1945 (Grip 1961; Martinsson 1996). Both the Geological Survey and the Boliden company continued nickel exploration and the most intense period occurred during the 1970-1980ies when several deposits were discovered, primarily south of the Skellefte district (i.e. Lappvattnet where trial mining occurred).

After the change of the mineral legislation in the 1980s, a short boom in diamond exploration occurred in Sweden following high prices and major discoveries in other shield areas, and in Finland. In recent years exploration related to graphite, mainly focussed on known deposits has been initiated (Talga)

\section{Price and demand}

The strongest driver for exploration is of course a high demand which in turn normally leads to increased 
commodity prices. While this was true already in the early days it has become more evident after the industrial revolution and initiation of a more global trade pattern. The response to market conditions in Sweden has largely followed this rule, although the relation between the state and private investors has shifted over time based on legislation. The fluctuations in copper price over time is illustrated in Fig. 1 where it is evident that peaks in prices are often related to major global crises such as major wars and other similar crises. One example how the price influence copper exploration in Sweden is the price increase starting in the late 1950ies until the oil crisis in 1974. During this time technical development has seen a boom in copper production from open pit operations of low-grade high tonnage type deposits globally (i.e. porphyry copper deposits). The Boliden company therefore intensified its exploration for this style of deposits and put the Aitik, low grade-high tonnage $\mathrm{Cu}$-deposit in production in 1967.

Another good example is the gold price over the last hundred years, seen in Fig. 2. The rapid increase in price starting in the 1960ies and lasting into the 1980ies corresponded roughly with the change in mineral legislation in Sweden in the early 1980ies opening up for exploration by international companies. This also influenced domestic exploration, largely in these days carried out by the Boliden company. By strategically focussing on gold exploration no less than three mines were opened over the period of 5 years: Enåsen (discovered earlier but put in production 1984), Björkdal (discovered in 1983 and put into production 1988), and Åkerberg (mineralization known since earlier, but economic mineralization discovered in 1987 and mine put into production 1989).
Another interesting effect of commodity price is the renewed interest in iron ore exploration in Sweden. Since LKAB closed down their exploration in 1986 no iron ore exploration was carried out in Sweden, not even in the LKAB mines in Kirunavaara and Malmberget. However, the commodity super cycle that started roughly around 2003-2004 also included iron. The first peak of iron ore price (see Fig. 3) occurred in 2007, just before the global economic crash in 2008. Although this crash strongly influenced the iron ore price, it soon recovered. During this boom several international and also domestic junior companies invested in iron ore exploration and in some cases are still involved in trying to reopen old iron mines. A special case is the company Northland resources. This Canadian company was listed on the stock exchange in Toronto and commenced businesses in Sweden in 2003, largely due to the boom in iron ore prices. In 2005, it changed its name to Northland Resources Inc. and commenced exploration and mine development activities in northern Sweden, especially the Kaunisvaara project. The mine was developed during the recovery of the commodity super cycle and commenced mining in 2012. A this stage the prices had peaked and started to fall dramatically (see Fig. 3). In 2014 the company filed for bankruptcy and the trading of the shares was suspended. Several trials were made to reconstruct the company or sell the property failed and, in the end, this turned out to be one of the largest bankruptcies in Swedish history. In September 2017, the trustee in the bankruptcy signed an agreement with the company Abecede $A B$ (later Kaunis Iron $A B$ ), which became the owner of the mine and restarted production in 2018.

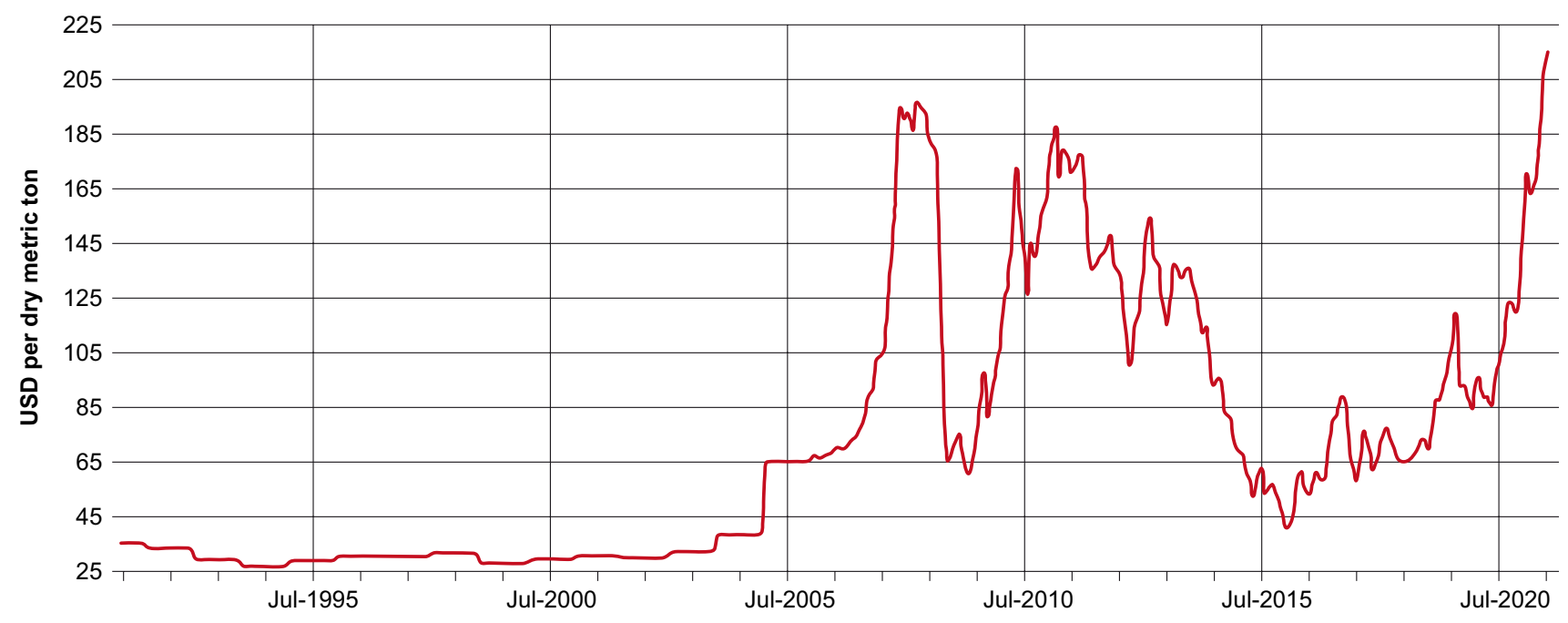

Fig. 3 Iron ore monthly price 1991-2021. Modified from Indexmundi (https://www.indexmundi.com/commodities/?commodity=iron-ore\& months $=360$ ). Iron ore (any origin) fines, spot price, c.f.r. China, $62 \% \mathrm{Fe}$ beginning December 2008; previously $63.5 \%$ 


\section{Technology}

\section{Drilling}

Development of drilling technology is perhaps the most important technological driver for increased success in exploration. The diamond core drill was invented in 1863 by Rodolphe Leschot, a French engineer (cf. Burt 2014). The 1865 experimental diamond core drills as well as the earlier one by Leschot consisted of a hollow tube or cylinder having a number of stones set on the bit end. The idea of using jewels or stones as cutting faces came from Leschot's early experience as a watchmaker, a concept which he successfully applied as a tunnel engineer. John Vivian was given the first US patent for a diamond drill 1876. While other drills before its time bored holes through a succession of blows, this invention allowed the core to remain intact, making it very valuable for prospectors. Edmund J. Longyear drilled the first diamond core hole in the Mesabi Iron Range in northern Minnesota 1890. Shortly thereafter, he formed a contract diamond drilling company to serve the rapidly growing U.S. iron ore mining and steel industry (http://www. petroleumhistory.org/OilHistory/pages/Diamond/inventor. html). In 1886, the Swedish drilling company Svenska Diamantborrnings $\mathrm{AB}$ was established and with equipment purchased in the US, diamond drilling for exploration purposes commenced. The purchased equipment was not ideal for hard rock drilling in Sweden and technical development by the engineer and CEO P.A. Craelius developed more functional drilling equipment. Svenska Diamantbergborrnings $\mathrm{AB}$ was part in the formation of $\mathrm{AB}$ Elektrisk Malmletning (now ABEM) in 1923. In 1953, Svenska Diamantbergborrnings AB had around 770 employees. In 1960, Svenska Diamantbergborrnings AB was taken over by Atlas Copco, which in 1978 moved its operations into Atlas Copco Craelius AB, which in 2014 became part of Epiroc, when Atlas Copco consolidated all its activities related to mining in that company.

Exploration drilling is today carried out by various drilling techniques. It is not uncommon today to drill holes which are longer than $1000 \mathrm{~m}$ and recover core from the entire hole. Today with modern technology it is possible to steer and guide drilling in order to orient both the drill hole (in digital software) and the drill core in 3D. Besides diamond drilling reverse circulation drilling, $\mathrm{RC}$ drilling is used for faster and shallower drill holes for grade control and drilling near surface targets. Contrary to diamond drilling, it collects rock cuttings instead of core. The drilling mechanism is most often a pneumatic reciprocating piston called a hammer, which in turn is driving a tungsten-steel drill bit, able to crush hard rock. It is faster and cheaper compared to diamond drilling and has been used in Sweden, primarily for resource drilling, to define grade and tonnage of a specific deposit.

\section{Geology}

\section{Mapping techniques}

Over the past hundred years the technical development of satellite imaging and GPS has of course revolutionised exploration since resolution in geological mapping has improved tremendously. Exploration and "expeditions" for the search of mineral wealth before the industrial revolution, especially in the northern part of Sweden were major undertakings into remote areas without any roads and in many cases unmapped or at least very poorly mapped. In these days, ore searching expeditions relied heavily on communication with local people. In the north this was done to a large extent by communication with the reindeer herding Sami population. Several major discoveries were made this way.

The industrial revolution in the mid nineteenth century also made land more accessible, railroads were built, and roads made remote land more accessible. This was also the time when the Geological Survey of Sweden was established (1858) in order investigate and document the mineral potential of the country in a more systematic way. At the same time (1859) production of modern geographical maps, the older economic map, usually called the district map (Häradskarta), and military topographic maps (Generalstabens topografiska kartor) started. This meant that the geological mapping and the search for mineral occurrences could be executed in a more effective way, although resolution was still an issue. Exploration and mapping of mineral discoveries relied on these maps for geographical positioning into the 1980s (the production of both map series ended in 1950), when also aerial photos were made available for large parts of Sweden.

From 1980ies and onward the resolution in aerial photos together with the development of the GPS technology and the introduction of telecommunication (NMT, 3G, 4G etc.) has helped exploration tremendously. Today geological mapping and geophysical measurements are carried out in real time with a $<1 \mathrm{~m}$ resolution (se chapter on Data management and Digitalisation). The proof of the fact that we are now truly in the digitized world in this respect came in 2017 when the national Land survey announced that will stop print geographical maps. Today printing is on demand and exploration is using digital maps in GIS-systems in computers or tablets, which are communicating with databases in real time in the field.

To a large extent exploration drilling is focussed on extracting cores of the bedrock by means of diamond drilling. These cores can have different diameter (see above in 
the chapter on drilling technology) and constitute, besides direct studied of outcrops in the field, the best material for geologists to study in order to identify economic mineral deposits. Drill core logging has therefore been a key ingredient in exploration over the last hundred years or so. Drill core logging has followed the same technical development as field mapping and today larger exploration companies have their own digital systems for integrating geological information based on core logging directly into their databases, where geological and geophysical data are combined to build robust geomodels. Drill cores are also important for assaying and defining grade and tonnages of any given mineral occurrence.

\section{Boulder tracing}

The Fennoscandian shield was glaciated during the last ice age and when the inland ice retreated c. 10000 years ago it left glacial deposits all over Sweden. Sweden is therefore characterized by large moraines covering the bedrock. In fact, large areas of Sweden have less than $1 \%$ of outcropping bedrock. This has essentially meant that boulder tracing and the hunt for mineralized boulders in the moraine has been a major technique to discover mineralized bedrock into modern days. Over the years this technique has been refined and combined with understanding the direction of ice movements by moraine stratigraphy and the realizations that the transport of erratic mineralized boulders from its source to the deposition in the moraine can be extremely complex. Several ice movement directions can occur in one place and the back tracing from deposition to source can be complicated. Both the state-controlled exploration through the Geological Survey and private companies such as Boliden have made many of their major mineral deposit discoveries using boulder tracing.

The importance of boulder tracing can be exemplified by the reports made by Josef Eklund at the Geological Survey of Sweden in 1950 (Eklund 1950a, 1950b). He discussed in the report "The history of ore searching in the Skellefte District and the contribution made by the Geological Survey" (free translation of the Swedish title "Malmletningens historia I Skelleftefältet och SGU:s insats") how the mineralzations had been discovered and concluded (translation from Swedish): "It can be concluded that the Geological Survey has made most of its discoveries ( 7 of 12) during large geophysical measurements in target areas. In the other cases discoveries of mineralized boulders by local people have been critical in 4 cases and in 1 case geological mapping for mineralizations was decisive. In the case of the Boliden company the proportions are different. According to my knowledge the following deposits have been discovered by boulders or in outcrops by local people...(13 deposits are listed) and their own boulder tracers have found 2. By means of electrical prospecting the following deposits have been discovered: Boliden, Kedträsk, Svansele (partly) Mensträsk (partly) $04 \ldots$.

Of the discoveries made by the Geological Survey 58\% have been found by geophysical measurements, by Boliden $21 \%$. Of the geophysical measurements 3 out of 11 were magnetic measurements...The reason why Boliden has been ahead of the Geological Survey is that they gathered large amount of information about boulders from the local people in $1921 \ldots$...By the end of 1921 Boliden had identified 2/3 $-3 / 4$ of their current major discoveries in the Skellefte district" (Eklund 1950a). This shows the importance of boulder tracing for the modern mining history of Sweden.

\section{Metallogeny and ore deposit models}

Although the understanding of how ore deposits form had undergone major refinement during the first half of the twentieth century, not the least after the classical work by Waldermar Lindgren, the Swedish-American geologist, who in 1913 published the book "Mineral Deposit" (Lindgren 1913), it was not until the modern plate tectonic concept were accepted during the 1960ies and 1970ies, that the impact of metallogenetic studies also influenced Swedish exploration. Metallogeny is the study of the genesis and regional to global distribution of mineral deposits, with emphasis on their relationship in space and time to regional petrologic and tectonic features of the Earth's crust. The understanding of how ore deposits form in space and time led to large debates on how the sulphide ore in both Bergslagen and the Skellefte district formed. A perhaps even more lively debate is the genesis of the Kiruna type magnetiteapatite iron ores, a debate that is still ongoing. One example how metallogenetic thinking shapes exploration strategies is the understanding of how the massive sulphide ores formed in Bergslagen and the Skellefte district. The understanding that the Swedish massive sulphide deposits resembled modern sea floor deposits and thus formed on (or just below) the sea floor almost 2 billion years ago as exhalative and sub-sea-floor replacement deposit was a major breakthrough (cf. Koark 1962; Rickard and Zweifel 1975; Lundberg 1980, Vivallo and Claesson 1987, Allen et al. 1996a, b) This led to a refinement of exploration models, especially in the Skellefte district by the Boliden company. The models involved a better understanding of metal zoning in the deposits as well as a better understanding of the 3D shape. A good summary of the development of metallogenetic models in Sweden and the Fennoscandian Shield can be found in Weihed et al. (2005).

With the growing understanding of genetic and metallogenetic aspects of ore formation and the comparison between younger geological terrains and ancient Precambrian shield 
areas, such as the Fennoscandian shield, conceptual models for different ore types started to emerge in Sweden during the last 40 years. This led to the definition of genetic models for volcanogenic massive sulphide (VMS) deposits (Koark 1962, Vivallo and Claesson 1987; Sundblad 1994; Allen et al., 1996a, b; Rickard and Zweifel 1975), orogenic gold deposits (cf. Weihed et al. 2005), porphyry style deposits (Weihed 1992, 2015) and iron oxide-copper-gold (IOCG) deposits (Martinsson et al. 2016) among others. After the changes in the Swedish mining legislation in 1982 (see above), these conceptual models led to an increase of international exploration companies willing to invest in Sweden. The geological potential of the region was realized, and the international companies brought their own expertise on exploration methodologies for these different types of ore deposits. One example of successful green field discoveries is Storliden in the Skellefte district (NAN, Lunding mining). Another good example how ore deposit modelling guides exploration strategies is the incorporation of modern volcanology into the exploration strategies of the Boliden company in the 1990ies. The concept was brought from Australia to Sweden by the Australian geologist Rodney Allen, who introduced volcanic facies mapping both in the field and in drill core. The work led to a change in the exploration work concept in the Boliden company and has guided especially brown field exploration in both Bergslagen and the Skellefte district and led to the discovery and extension of ore bodies in both areas. (cf. Allen et al. 1996a, b).

\section{Geochronology, isotope geology and microanalysis}

Technical breakthrough in geochronology and microanalysis have also played a major role for exploration and the discovery of new ore deposits in the last 50 years. The understanding of timing of ore formation is an important tool in modern exploration as it makes it possible to correlate ore forming events in time. Surface mapping before the industrial revolution made spatial correlations possible to some extent, but drilling techniques and later geophysical techniques have made spatial correlation possible in 3D down to several kilometres in the earth crust (see below 3D modelling). However, with the possibility to unravel the time of formation and in cases also several overprinting ore forming events have also made it possible to correlate coeval events and "see through" later deformation and metamorphism that can displace or disperse (or concentrate) mineral occurrences. Refined geochronological methods has over the last 50 years gone from rough age dating of bulk samples to spot dating of individual mineral grains to unravel a complete evolutionary story. Geochronology coupled with detailed structural studied of the deformation history of ore bodies now allows for 4D reconstruction of a mineral belt (see below). In Sweden, geochronology and isotope geology has made a large impact on our understanding of major mineral belts, such as Bergslagen, the Skellefte District, and Norrbotten. Excellent reviews on this can be found in (Bergman et al. 2001; Kathol and Weihed, 2005; Stephens et al. 2009).

In parallel with the development of geochronological techniques, microanalysis has developed. With modern analytical equipment such as SEM, TEM, LA-ICP MS. it is now possible to study and chemically analyse minerals and rocks in sub nanometre scale. This development has made it possible, not only to assay samples in a faster and better way, but also to study multiple mineralizing events over time in a single mineral grain, guiding exploration geologist to improve their exploration models. In Fig. 4, one example from the Älgträsk gold deposit exemplifies this (Bejgarn 2012).

\section{Geophysics and remote sensing}

A strong driver for exploration success over the last hundred years has been the development of geophysical exploration methods. In Sweden this development has had an immense impact on the discoveries of both iron ores, base metals as well as precious metals. While magnetic measurements were developed during the second half of the nineteenth century after the invention of the first magnetometer by Carl Friedrich Gauss in 1832, it was not until after the first world war that it was used in a more systematic way. Also, electrical and later electromagnetic methods were applied to discover the massive sulphide deposits in the Skellefte district. In Sweden the first attempt with electrical methods were made by W. Pettersson and K. Wallin in 1906 who conducted experiments on electrical conductivities of different metals according to the method developed by Daft \& Williams (cf. Lundberg 1922) and in a more practical exploration situation by Bergström (1913) at the Geological Survey of Sweden . Pioneering work by in 1918 by Lundberg and Nathorst (AB Bergsbyrån) with a new electrical survey equipment, for electric equipotential line measurements, was the real breakthrough for electrical prospecting in Sweden and a number of new sulphide ores, especially in the Skellefte district (i.e. Kristineberg in 1918), were detected in the coming decade, much due to this new exploration technique.

The first use of electromagnetic (EM) instrument was developed in 1921 by Centralgruppens Emmissons AB, predecessor to Boliden (Sundberg et al. 1923) and among other ore bodies the Boliden deposit was discovered by this method. Due to the fact that black schists and massive sulphides were indistinguishable with the early EM method (två ram metoden), see Fig. 5a, the Boliden company continued its technical development of geophysical instruments and in 1935 launched their own gravimeter. The home-built gravimeter was in 1950 exchanged for the lighter and more flexible Worden-gravimeter. Discoveries made with this 


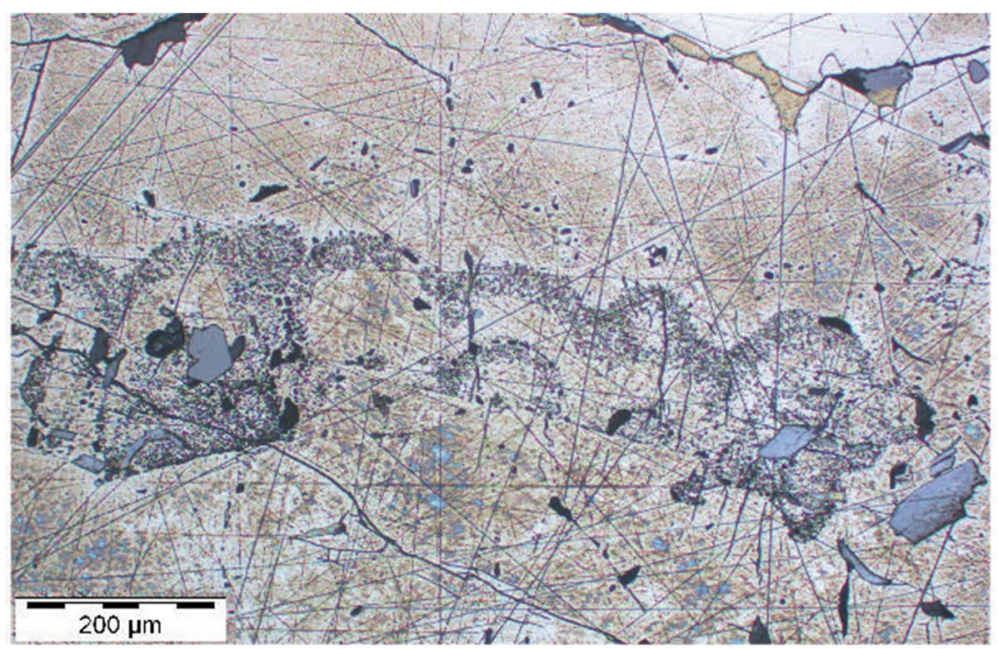

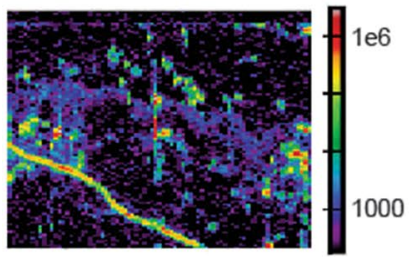

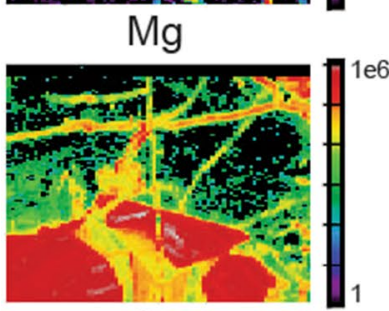

Co

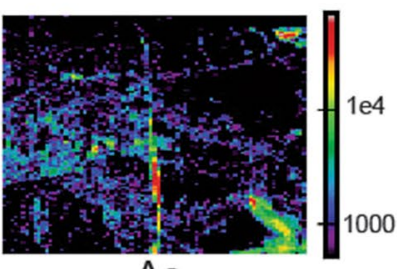

As

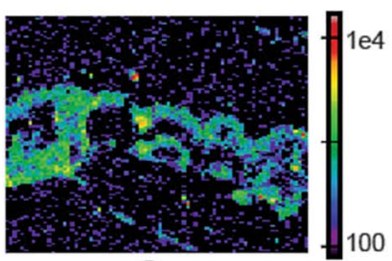

Sn

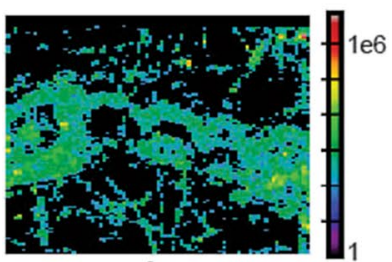

$\mathrm{Au}$

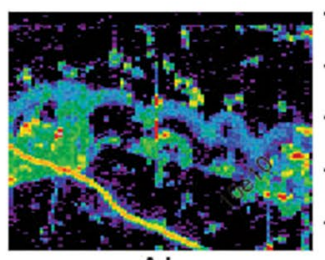

Al

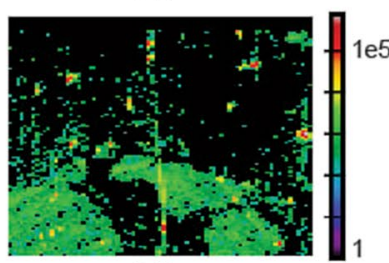

$\mathrm{Ni}$

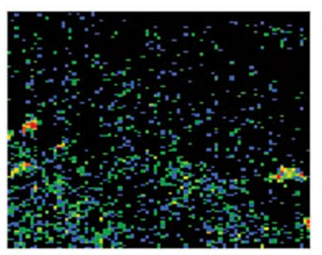

$\mathrm{Se}$

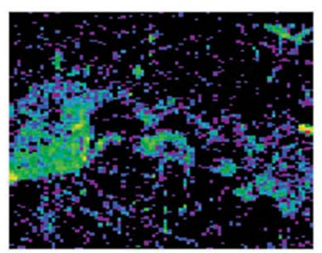

$\mathrm{Sb}$

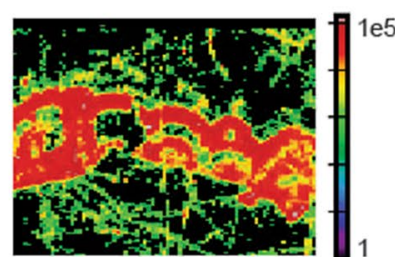

$\mathrm{Pb}$

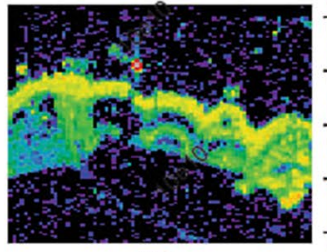

$\mathrm{Ti}$

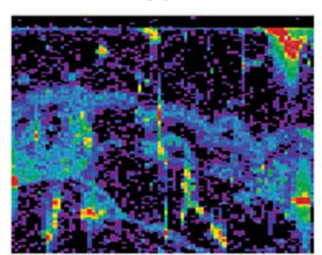

$\mathrm{Cu}$

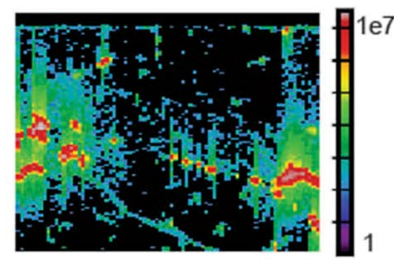

Mo

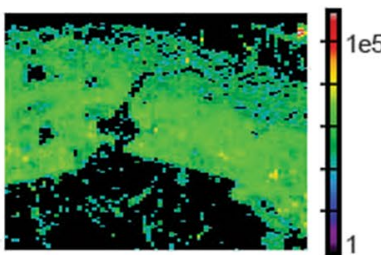

$\mathrm{Te}$

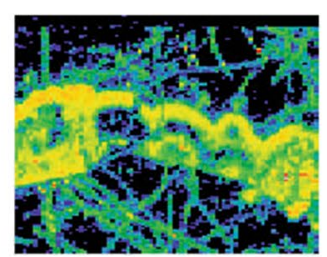

$\mathrm{Bi}$

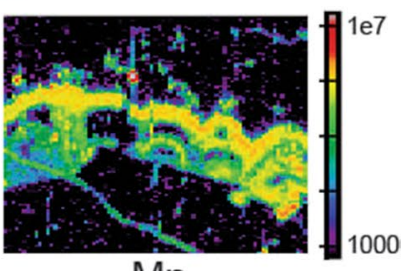

$\mathrm{Mn}$

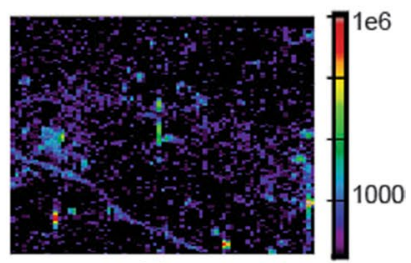

$\mathrm{Zn}$

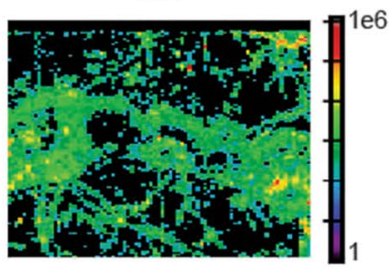

$\mathrm{Ag}$

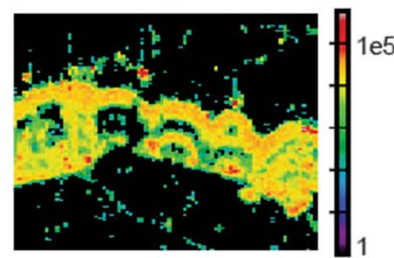

W

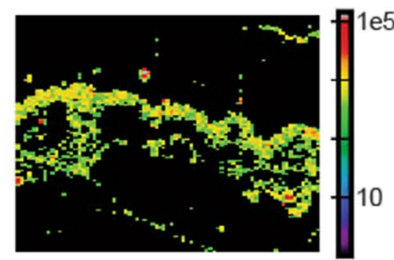

U

Fig. 4 An example of modern SEM analyses and the possibility to map elements within a mineral grain to unravel the evolutionary history of a mineral deposit. Data from Älgträsk, Northern Sweden (Bejgarn 2012) 

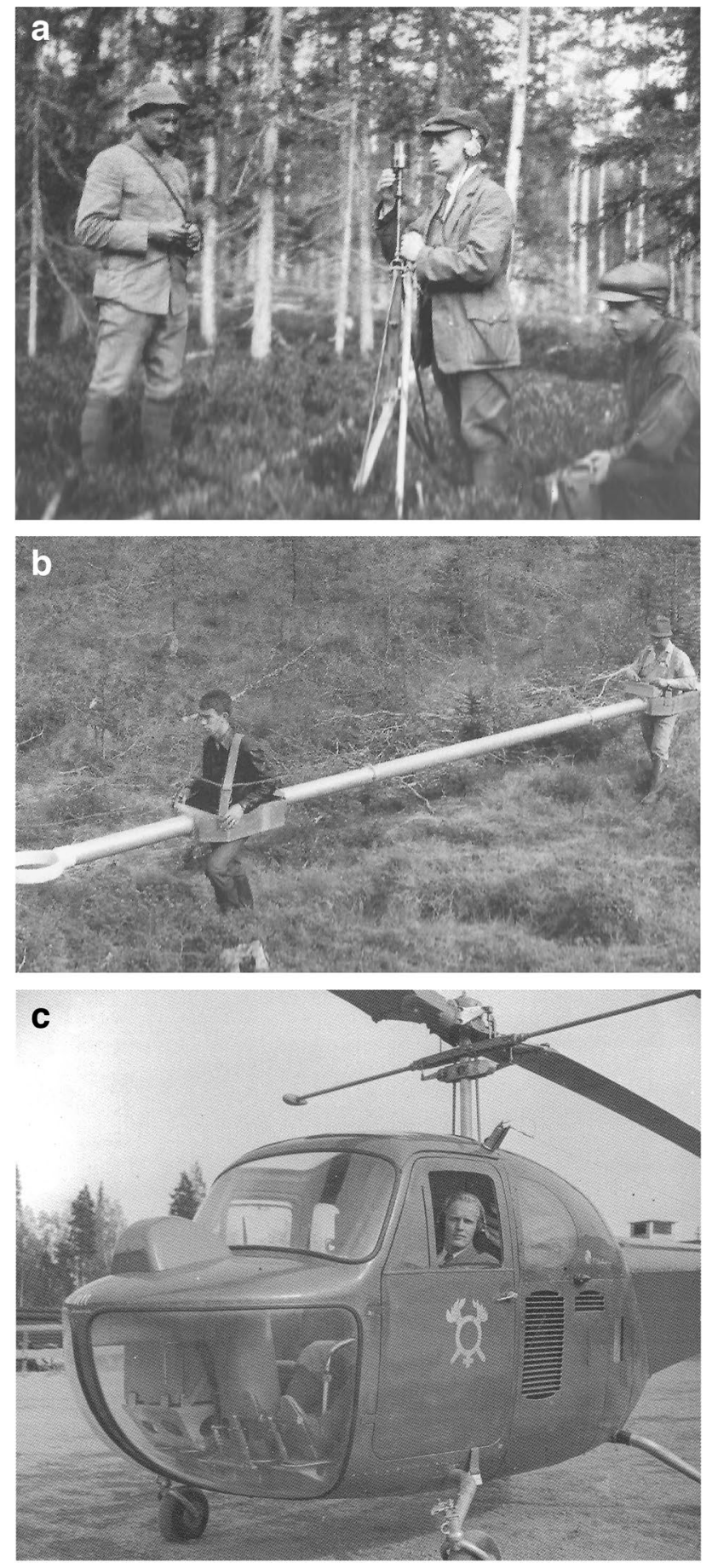

Fig. 5 Examples of geophysical innovations for exploration by the Boliden company. Photos from Lundqvist (2013). Published with permission from New Boliden AB. "Compensation method" reading in the field from 1937. a) "två-slingram" measurements, b) Boliden helicopter with an installed magnetometer 1948

method include the ore deposits Näsliden south and Udden in the early 1950ies.
Pioneering work was also made by AB Elektrisk Malmletning (ABEM) who developed two electromagnetic methods (kompensator and turam). With these methods the depth penetration of the surveying increased.

The EM Slingram method was invented in Sweden in 1936 by Sture Werner and Alfred Holm based at the Geological Survey of Sweden. The method was used also by the Boliden company after the world war II. Continued development of the slingram method (cf. Fig. 5b stångslingram) was done by Boliden who used this exploration method until the end of the 1960ies for exploration of sulphidic ores.

Rapid technical development for airborne surveying, based on instruments developed by the US air force (MAD system), commenced after the world war II. This can also be said to be a fundamental break-through in technology as much larger areas could be covered compared to ground measurements. Already in 1944, the US Geological Survey (cf. Fitterman 1987) flew the first airborne geophysical survey collected 10000 miles of magnetic data. In the 1950ies, Swedish development of the two-plane system that used a rotating field (Hedström and Tegholm 1956) and employed two specially positioned lights to aid the pilots in maintaining a fairly constant relative aircraft position was made. It achieved a high degree of penetration, but data interpretation was quite difficult. However, already in 1948, the Boliden company commenced with airborne magnetic measurements from helicopter (Fig. 5c) and in 1955 the first trials with airborne EM measurements were done. Airborne geophysical measurements have been carried out by the Geological Survey of Sweden since the 1960s. Today the quality of the airborne geophysical data covering large parts of Sweden is world class in terms of resolution (line spacing and altitude).

The price of copper increased in the late 1960s and with the opening of the low grade, high tonnage open pit $\mathrm{Cu}-$ deposit Aitik the Boliden company focussed on exploring for similar deposits during the 1970ies. This led to the development of the inhouse VLF and IP methods. However, already in the 1970ies exploration drilling for deep ores also meant that geophysical methods to be utilized in drill holes started to appear. Down hole radar was development in 1973 and the Boliden company was especially successful in developing their own methods for down hole EM measurements, starting in the early 1980ies. Continued instrumental development within the Boliden company also led to a shift from slingram measurements to the so called EM3 method (short for three dimensional electro-magnetic measurements) in the mid 1980s.

\section{Drill hole and core measurements}

In the last decades the technological advances in analytical chemistry and non-destructive methods have helped exploration geologist both in the field and in the core shed. 
Today hand-held XRF equipment allows for in situ chemical analyses in real time, and is used in exploration in Sweden and globally. Also drilling technology has incrementally improved and the possibility for on-site drill core scanning and analyses. This technology has been led by two small Swedish tech companies Minalyze and OreExplore. The Minalyze company (https://minalyze.com) patented their XRF core scanning equipment Minalyzer CS (Fig. 6a) in 2014 for fast chemical, structural, density and imaging of drill cores and are now operating primarily in Australia. Similarly the Swedish company Orexplore (https://orexp lore.com) has patented the core scanning equipment GeoCore X10 (released on the market 2018, Fig. 6b), which originally evolved from medical imaging technology, to provide non-destructive, on-site structural 3D imaging, geochemical drill core sample analysis.

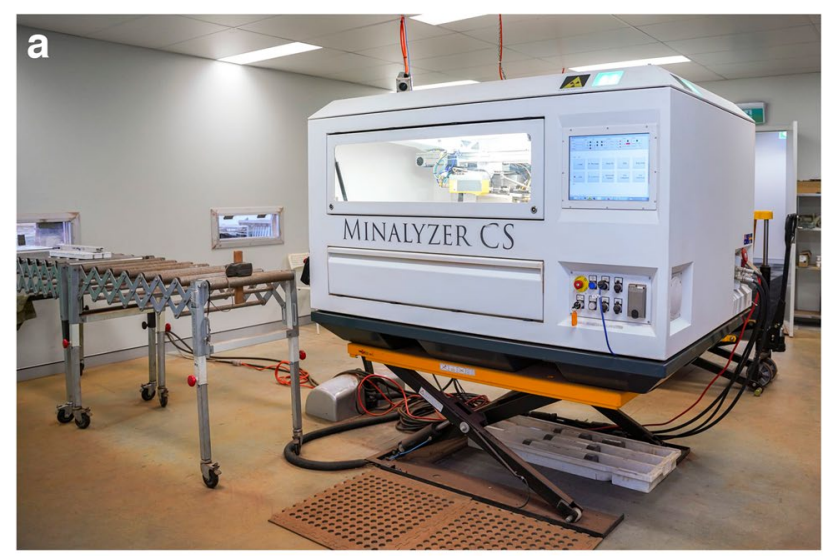

b

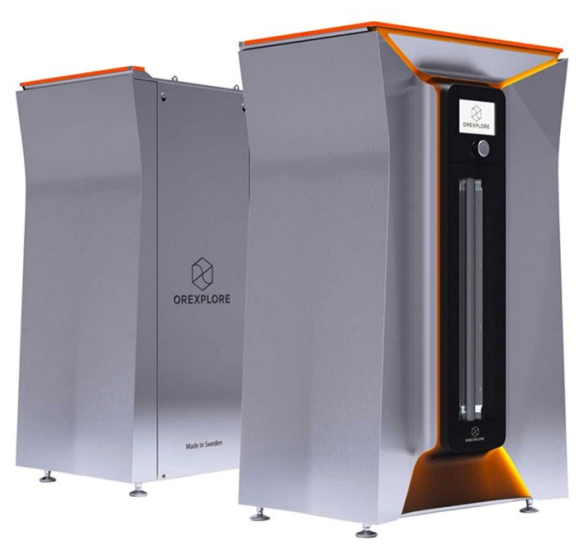

Fig. 6 Examples of two modern Swedish innovations that guides modern exploration. Both technologies are based on semiautomated drill core scanning and non-destructive chemical analysis in real time. a) The automated drill core scanner developed by Minalyze AB. Photo from https://minalyze.com/mines-to-build-advanced-geosc iences-lab-for-non-destructive-analysis-of-drill-core/, b) The GeoCore X10 of Orexplore AB. Photo from https://orexplore.com/ourstory/

\section{Geochemistry}

Assaying of rocks containing mineralization has always been a key to understanding the economic potential of a mineral occurrence. Swedish chemists were world leading during the eighteenth and nineteenth century, much attributed to the fact that many of the famous Swedish (also active in Finland before 1809), chemists discovered, identified and analysed no less than 19 elements in the periodic table, many of which came from samples from Swedish mines (see Table 1).

The real boost in geochemical exploration occurred when geochemical analyses became better, faster and cheaper after the world war II when the electronics industry exploded, and computers were introduced. The Geological Survey of Sweden founded their geochemical laboratory in 1940 (Landergren 1948), even if spectrochemical investigation of the minor constituents in iron ores was started as early as 1937 when Landergren studied spectrochemical research methods at the laboratory of V. M. Goldschmidt at the University of Oslo.

The period from the end of the world war II until the 1970ies was characterized by analytical chemistry going from wet chemical methods to more sophisticated quantitative and qualitative spectroscopic methods. The improved resolutions, lower cost and improved speed also changed

Table 1 Elements detected by Swedish scientist and place of discovery

\begin{tabular}{|c|c|c|c|}
\hline Element & Discovered by & Year & Mine \\
\hline Cobolt (Co) & Georg Brandt & 1730 & Los \\
\hline Nickel (Ni) & Axel Fredrik Cronsted & 1751 & Los \\
\hline Nitrogen $(\mathrm{N})$ & Carl Wilhelm Scheele & 1772 & \\
\hline Chlorine $(\mathrm{Cl})$ & Carl Wilhelm Scheele & 1774 & \\
\hline Oxygen $(\mathrm{O})$ & Carl Wilhelm Scheele & $1773-1777$ & \\
\hline Manganese (Mn) & Johan Gottlieb Gahn & 1774 & Falun \\
\hline Tantalum (Ta) & Anders Gustaf Ekeberg & 1802 & Ytterby \\
\hline Cerium $(\mathrm{Ce})$ & $\begin{array}{l}\text { Jöns Jacob Berzelius \& } \\
\text { Wilhelm Hisinger }\end{array}$ & 1803 & \\
\hline Selenium (Se) & Jöns Jacob Berzelius & 1817 & \\
\hline Litium (Li) & Johan August Arfwedson & 1817 & Utö \\
\hline Silicon $(\mathrm{Si})$ & Jöns Jacob Berzelius & 1823 & \\
\hline Thorium (Th) & Jöns Jacob Berzelius & 1828 & \\
\hline Vanadium (V) & Nils Gabriel Sefström & 1831 & Taberg \\
\hline Lantanum (La) & Carl Gustaf Mosander & 1839 & \\
\hline $\begin{array}{l}\text { Praseodymium (Pr) } \\
\& \text { Neodymium } \\
(\mathrm{Nd})\end{array}$ & Carl Gustaf Mosander & $(1841)$ & \\
\hline Erbium (Er) & Carl Gustaf Mosander & 1843 & Ytterby \\
\hline Terbium (Tb) & Carl Gustaf Mosander & 1843 & Ytterby \\
\hline Holmium (Ho) & Per Theodor Cleve & 1879 & Ytterby \\
\hline Thulium (Tm) & Per Theodor Cleve & 1879 & Ytterby \\
\hline Scandium Sc) - & Lars Fredrik Nilson & 1879 & Ytterby \\
\hline
\end{tabular}


exploration strategies in Sweden. As Sweden is a glaciated terrain, large scale geochemical exploration campaigns were focussed on till geochemistry and stream sediment geochemistry, besides, of course, bedrock and drill core geochemistry. In the 1970ies and 1980ies geochemical exploration was intensified in Sweden and exploration geologists at the Geological Survey and later the Swedish Geological company (SGAB, together with Boliden and LKAB developed the methodology. During the 1980s, exploration for gold was intensified in Sweden due to high commodity prices (se section on commodity prices above). Large scale geochemical exploration programmes led to the discovery of several gold mineralizations. The best example of successful geochemical exploration was the discovery of the Björkdal gold deposit in Västerbotten, Sweden.

The mineralization was discovered in 1983 by Terra Mining (a company started by geologists from the Geological Survey) during a geochemical till sampling programme and the mine was put into production in 1988. Today it constitutes one of the major gold mines in northern Europe (1.44 Million ounces mined at $1.32 \mathrm{~g} / \mathrm{t}$ in 2019).

The introduction of non-destructive in situ analytical techniques coupled with digitalization has also changed the concept of geochemical exploration. The Geological Survey has an open source database, MALMKEMI-d,b with chemical analyses of drill cores, rock samples and mining waste, which containing over 30,000 records (in Dec. 2018)

\section{3 and 4D modelling, and predictive modelling, data driven models}

The computer power that is available for exploration companies today allows for powerful integration and analysis of large amount of data. The consequences are that exploration is becoming more and more data driven and algorithms are continuously developed for integrating geological, geochemical and geophysical data to build 3-dimensional models at virtually all scales from deposits scale to more regional scales depending on whether your exploration strategy is near mine, brownfield or greenfield exploration. The 3-dimensional models are also modelled with geological time in 4-dimensional models where the evolution of a deposit or mineral district give guidance to exploration strategies. The latter is of importance when exploration is targeting mineralization at increasingly depth. Figure 7 illustrates how 3-dimensional modelling with an example from the Skellefte district. A comprehensive review is given in Weihed (2015).

Based on the increased understanding of mineralizing processes, host rock geochemistry, geochemical zonation related to ore formation, geophysical signatures etc. robust predictive models are today constructed for target areas. These models can be open source, commonly constructed by research groups at universities or geological surveys, or closed information that guides individual exploration companies in their decisions for target areas. A recent example for the Skellefte district can be found in Carranza Sadeghi (2010).

Augmented reality and virtual reality are today powerful tools especially for near mine exploration, where the 3-dimensional and 4-dimensional models can be integrated with other form of geodata. The AR or VR methodology allow the exploration geologist or geophysicist to enter into the 3D-space in a virtual way and interpretations to guide exploration can be made to improve the success rate in the exploration project of concern. One recent example where augmented reality is utilized in mineral exploration is the EU-funded FARMIN project (https://www.farmi nproject.eu), where researchers and exploration industry aim to improve the exploration success rate.

\section{Data management, digitalization, GPS and telecommunication}

Digitalization and increased computer power have radically changed exploration industry the last two decades. Today field mapping is carried out on computers and tablets with dedicated software, which in the field are connected via $4 \mathrm{G}$ or $5 \mathrm{G}$ networks directly to the databases of the exploration company. It is possible to get information updated in real time in most parts of Sweden. This has shortened the time from the first exploration permit to the application for a mining permit drastically.

Since the termination of state financed exploration the role of the Geological Survey has partly changed. Since the 1990ies the role of the Geological Survey has been to provide basic material in the form of databases, maps which are now in digital format, and access to older exploration material, including drill cores and exploration reports. The establishment of the Geological Survey office in Malå with this dedicated service in the 1990ies has been an important tool to attract private investment in exploration from both international and national exploration industry. Today a large part of the older exploration records and literature are available online and new data from mapping projects are continuously fed into the online databases. It should also be mentioned that the establishment of the national core archive, where drill core from exploration programmes, both state and privately funded, are stored and are available for inspection.

\section{The mining legislation}

Undoubtedly, the mining legislation and changes over the years has played a major role for the investment climate in exploration. The role of the Swedish state has been strong 


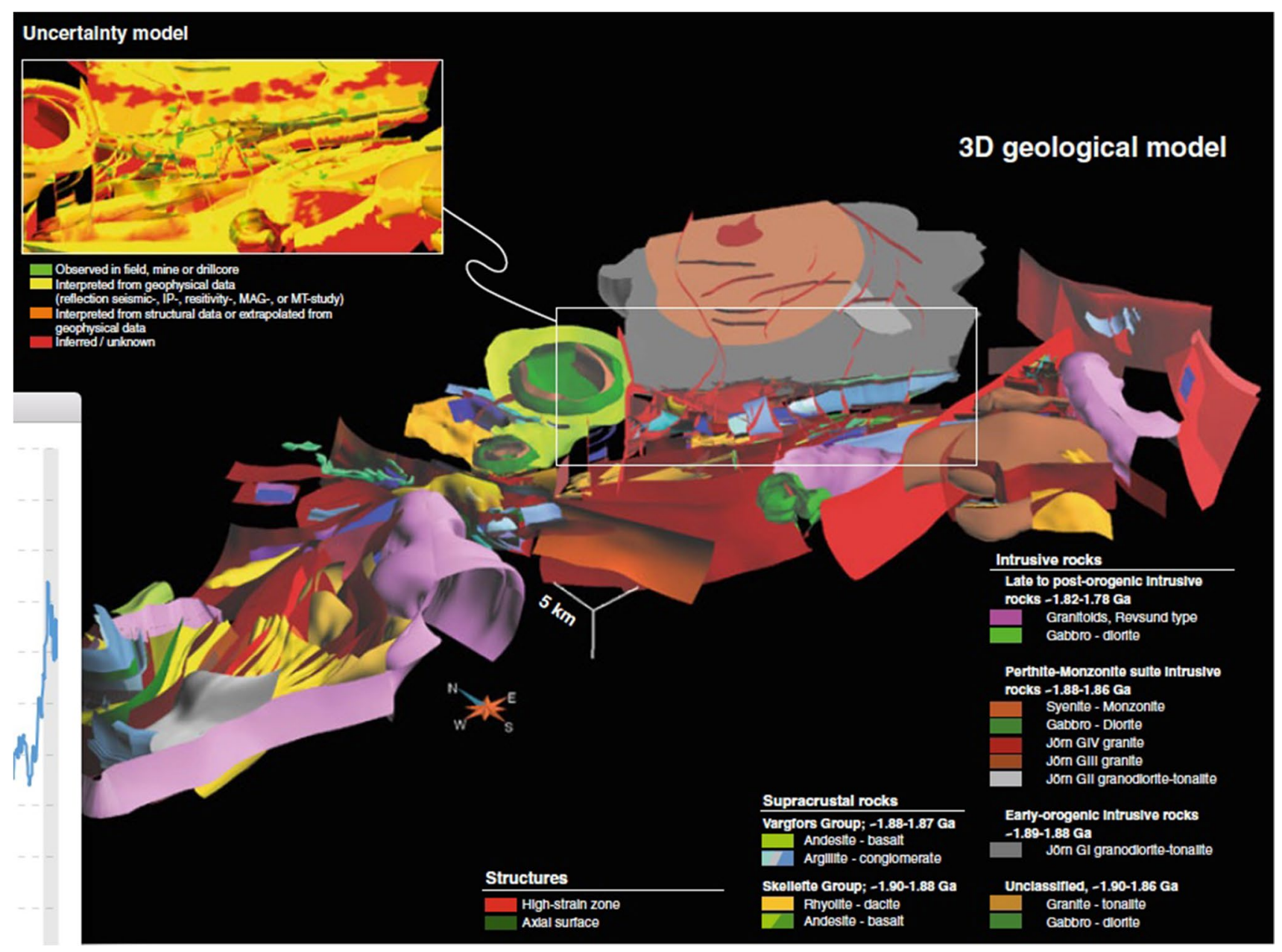

Fig. 7 An example of a 3d model to guide exploration. Case study from the Skellefte district (Bauer et al. 2015)

and in periods the state, or crown, controlled mining and exploration. Until the 1980ies exploration and mining was basically a domestic industry. Changes in the mining legislation opened up for international investment in exploration and this dramatically changed actors on the Swedish exploration market.

\section{Medieval mining rights}

The text below is based on the review by Rinander (2013) of the development of the mineral act in Sweden. The first Swedish mining legislation as we know it dates back to the fourteenth century. Through this mining legislation, fee regulation for mining rights was established in favour of the Crown. However, it was not the Crown that owned the land and the mines, instead the ownership of the mineral belonged to the landowner. Essentially exploration and mining were done by landowner or any other prospector. The Crown had the right to one tenth of the income in tax (tionde in Swedish). In the fifteenth century, mining legislation defines the
Crown's right to tax from mines depending on ownership of the land. During the 16th and 17th centuries the Regal rights were strengthened to include mines on all land. However, the sovereign rights of the Crown decreased the incentives to engage in mining and exploration. The nobility reacted against this and demanded nobility privileges which gave them mining rights on their own land, provided that $1 / 30$ of the income was paid in tax to the Crown and during the seventeenth century privileges granted by the Crown aimed at stimulating mining. For example, Queen Kristina gave the finder of mineral deposit six years' freedom from tax (tionde).

\section{Claims}

This old legislation was abandoned in 1723, in favour of the claim system. The claim system meant that anyone who discovered a mineral occurrence could acquire exclusive right to mine it. The landowner was assured mineral rights on his own land. If landowners did not exercise their rights 
to mining the rights could be shifted to private explorers. In the eighteenth century, the finder's right to minerals was extended at the expense of the landowner, mainly because some landowners sought to prevent mining on their land, against the will of the Crown. The claim system strengthened the rights of the claim holder further during the latter half of the eighteenth century. In 1855, a new mining act was introduced were the landowner's interests were strengthened with a protected zone of $175 \mathrm{~m}$ (100 famnar) from houses and farms, inside of which mining activities required the landowner's permission. The Crown waived its land ownership share on crown land for the benefit of claim-taker, i.e. the mining company. According to the 1855 mining act, the landowner could claim an annual the fee or future compensation. Furthermore, the landowner was entitled to half of the mining company and thus a share in both profits as costs. Applications for mineral exploration and mining should be in writing to the mining inspectorate and include geographical area and the commodities sought for (similar to the current conditions). The claim right above all meant an exclusive right to explore an area for mineral occurrences, and a mining concession was required to start mining. However, claims made on the basis of the 1855 mining act were in conflict with the privileged exclusive right to mining which rested on privileges from the eighteenth century. In 1884, therefore, a new mining act was introduced and in 1889, a ban on mining concessions on Crown land was announced, which can be seen as a reaction to the fact that the Crown share had been forced to be abandoned.

\section{The Crowns share}

During the beginning of the twentieth century the state wanted to strengthen its control over mineral extraction, and a ban for claims and mining concessions on state land were introduced. In a parliament investigation the interest to secure the supply of minerals and metals was considered to best be met through a continuation claim system that assured the discoverer a real right to the deposit. This would stimulate individual companies to make investments in exploration. The mining legislation experts' report was the basis for a bill in 1936, and in 1938 a new mining law replaced the 1884 mining act. The landowner share was eliminated, instead this right was handed over to the state which was entitled to half-share in mining enterprises. The state share was called the crown share (kronoandel in Swedish). The landowner was entitled to a landowner's fee of $1 \%$ of the value of the extracted mineral. In 1974 (1974:890), a new mining law came into force. The right to landowner compensation from the mining company disappeared.

A good review of the rather radical change in exploration that appeared in the 1980 and 1990ies in Sweden can be found in SOU 1996:152, and the text below is largely based on excerpt from this publication. A new mineral legislation was adopted in July 1992 (1991:45). The Minerals Act 1991:45 replaced the which replaced the Mining Act and the Act on Certain Mineral Deposits (Bill 1988/89: 92, amendment 1990/91: NU7), which in turn had replaced the Mining Act 1974: 342 and the Act 1974: 890 on certain mineral deposits. The Mining Act was still based on the claim system, which meant that the person who first applied for a permit to investigate an area with regard to on the presence of recoverable minerals according to a specification specified in the law, was given the exclusive right. The law on certain mineral deposits was based on the concession system, which did not give an obvious right to those who applied for a permit to explore an area. Permission could be given to anyone the government found most appropriate and the permit could be combined with conditions that were decided in each individual case. In the claim system, there was also a preferential right for the person or company that held the claim to mine a mineral deposit if mining profitability could be demonstrated. There was no such obvious right in the concession system. In the new Minerals Act, these two systems have been merged in a concession system with strong elements of the claim system.

\section{Modern mining legislation}

The Minerals Act was amended in 1993 by deleting chapter 11, which meant that the Crown share was removed. The reason to this measure was that the state would no longer engage in exploration. The state had since 1973 executed state-controlled exploration through Board of State Mining Property (NSG) and in 1993 a governmental decision was taken to close this organization down and cease statecontrolled exploration. The government therefore wanted to remove the regulations that appeared to be the most hindering for exploration companies, especially foreign companies that were not used to the current system in Sweden. The Crown share was not strictly applied for all mining operations. Instead, a practice had been established with agreements where the state instead leased out its half share to the operators for a certain amount of compensation. The remuneration was generally designed as a profit-sharing system. This measure thus meant that the state in practice received a form of royalty instead of a share in the mining operations. The management of the Crown shares as well as virtually all other mining property belonging to the state was handled by Board of State Mining Property (NSG). The opportunities for foreigners to acquire mineral rights in Sweden were regulated in the 1982: 618 Act on Foreign Acquisitions of Real Estate, etc. The Act prescribed that foreigners must have a permit to obtain claims or mining concessions under the Mining Act. This applied also to Swedish companies 
that have a certain share of ownership in foreign hands. Many foreign companies, as well as many Swedish ones, perceived that the law entailed a ban on obtaining a permit under the Mining Act and therefore refrained from even trying to obtain claims. The law was thus perceived as a major obstacle for foreign prospectors. However, the application of the law was not strict. The companies that applied for a permit generally received this and were able to prospect on largely the same terms as Swedish companies. A very good example was the Belgian company Vieille Montagne that operated Zinkgruvan mine between 1857 and 1994 and had during this time on several occasions received such a permit.

The discontinuation of government exploration is one in a series of measures taken at about the same time. The closing down of Board of State Mining Property (NSG) included the liquidation of Sveriges Geologiska AB (SGAB 19821994), which was established as a state-owned company in 1982 to carry out commissioned exploration. The company was a break-out of the Geological Survey of Sweden, which was thereby divided into an authority with the task of mapping Sweden from a geological point of view and a company with the task of conducting primarily exploration activities. The main client was Board of State Mining Property (NSG). At the same time, the mineral policy authority tasks were transferred from the then Statens Industriverk SIND to the Geological Survey of Sweden.

The mining legislation has seen minor adjustments the last 30 years. Sweden joined the European Union in 1995 and this also meant that Sweden fully opened up for investments from the EU internal market, and labour mobility within the EU. The Mining inspectorate was in 1998 incorporated into the Geological Survey of Sweden, after 350 years as an independent authority (see above). The Mining inspectorate, however, kept their independent role as for decisions taken regarding claims and mining concessions. In 2000 the (SOU 2000:89) it was proposed that, the mineral compensation payed by the mining company should be $2 \%$ of the value of the mineral extracted. The mineral compensation is split between the landowners and the state ( 1.5 and $0.5 \%$ respectively). From this work it was also obvious that more emphasis was put on environmental issues related to exploration and mining after the introduction of the Environmental Code (1998: 808) on 1 January 1999 , which meant that further environmental considerations must be taken into account in a number of different areas of activity.

The consequences for exploration of the new mining act from 1992 can be summarized as two major market reactions: 1) Increased international presence in Sweden combined with a fundamental increase in investments in exploration (see Fig. 8) and 2) Increase in conflicts between stakeholders and mining companies. When the mining legislation was changed and opened up for foreign investment the number of claims made by international, and new junior national companies, increased dramatically. One of the more drastic consequences was that, since the cost for getting a claim, or investigation permit (undersökningstillstånd), was low by international comparison, the Australian exploration company Ashton Mining company claimed a large part of Sweden for diamonds, thus excluding this part from other exploration activities. This was an unwanted effect and costs for claims were adjusted and the Mine inspector were given more rights to evaluate the intentions and capabilities of the companies to defend/ explore the land they claimed.
Fig. 8 Exploration expenditures in Sweden over the last 50 years. Data from the Geological Survey of Sweden and SOU 1980:12
Exploration expenditure in Sweden 1955-2020 (MSEK)

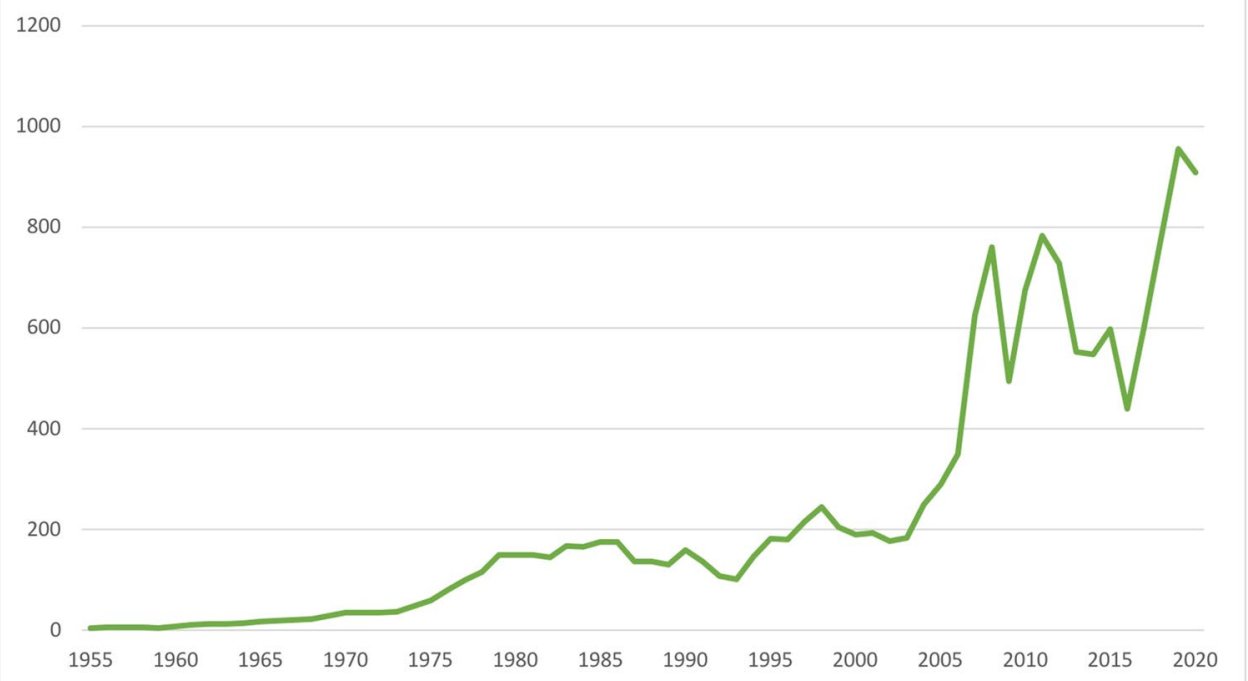




\section{1 st century and future development}

The twenty-first century has seen an increased focus on the raw material supply, and not the least the European union has identified security of supply as a main issue ( see https:// ec.europa.eu/growth/sectors/raw-materials/policy-and-strat egy-raw-materials_en). The Raw Materials Initiative was published (SEC(2008) 2741) in 2008. Here the commission the strategic importance of raw materials to the EU economy. This was followed by the first list of critical raw materials in 2011 where 14 critical raw materials were listed. The list has since been updated every third years and in 2014 contained 20, in 201727 and in 2020 contained 30 critical raw materials to the EU economy (https://ec.europa.eu/growth/sectors/ raw-materials/areas-specific-interest/critical-raw-materials_ en). The import dependence of these critical raw materials, i.e. REEs, Co, Li, , Phosphorus and Graphite, needed for the green transition has triggered increased focus on exploration for these commodities also in Sweden during the last 10-15 years. Together with the increased demand for base metals, especially copper, and iron, this has meant that investments in exploration in Sweden has increased dramatically since 2005 (Fig. 8). In Fig. 9, the current situation with regards to operating mines and mineral deposits where a granted exploitation concession or granted environmental permit exist, is shown (from Geological Survey of Sweden 2021).

The largest exploration companies during the last few years are the mining companies LKAB, Boliden and Zinkgruvan Mining AB, which together account for 90 percent of the exploration efforts in the country 2020. The renewed exploration efforts of the mining company LKAB has meant that exploration expenditures are now at record levels close to 1000 MSEK. The majority of the 2020 exploration consisted of near-mine exploration and was focused on Norrbotten and Västerbotten Counties.

Due to the expansion of LKABs exploration the proportion invested in iron exploration increased to $50 \%$ in 2020 , from $31 \%$ the year before. Exploration for so called critical raw materials, on the 2020 list of the European commission, accounted for only a very small proportion (Geological Survey of Sweden 2021).

It is evident that during the latest boom commodity prices until 2008 the number of valid exploration permits increased in Sweden (Table 2). Since the peak in 2008 the number of valid permits has decreased dramatically from 1322 in 2008 to 593 in 2021. Based on commodities, copper and gold dominate exploration with 66 and $62 \%$ of the exploration permits, respectively, followed by silver (41 percent), zinc (40 percent), lead (30 percent), iron (15 percent), cobalt (12 percent) and nickel ( 9 percent), tungsten ( 8 per cent), molybdenum ( 7 per cent) and vanadium, palladium, and platinum of $5 \%$ each (Geological Survey of Sweden 2021).
Although exploration expenditure currently is at a historically high level in Sweden it must be seen in the context of substantially fewer new grated exploration permits and the fact that the majority of exploration is near-mine and also an expected boom in exploration for critical raw materials (REEs, Co, Li, V, Graphite a.o.) has yet to be seen. This is discussed further below.

\section{Discussion and summary}

In this paper, I have review how three things 1) demand and price, 2) technical development, and 3) legislation, play a major role for exploration, based on Sweden as a case study.

Ultimately the demand is the key driver for both exploration and mining. The relationship between the demand and the supply (stock) of any given commodity also influence the price. The demand is also related to the economic development and crises such as major wars or global financial crises can shift the demand from infrastructure metals such as iron and base metals to investment metals such as gold. In Sweden this is perhaps best illustrated by the rapid increase in the gold price in the 1920s and in the 1980s. In the first case, this corresponds with intense exploration for both base and precious metals in the Skellefte district and the discovery of the Boliden deposit, until today the largest gold mine in Sweden with a production of 123 tonnes of gold (cf. Bergman Weihed et al. 1996), and the "gold rush" in the 1980s, when three gold deposits (Enåsen, Björkdal and Åkerberg) were discovered and developed into mines within only a few years.

The boundary condition for investing in exploration is a mining legislation that is open to these investments. Without doubt, the mineral wealth of Sweden has over several centuries played a major role in the development of the state, starting with early mining operations and the search for copper, silver and iron to sustain the crown in the sixteenth until the nineteenth century until todays situation when so called critical raw materials (REE, Co, Li a.o.) for the green transition has become a major political issue. In modern times the most fundamental change that impacted exploration is the 1993 change in mining legislation. As discussed above this change meant two things 1) state financed exploration ceased and international capital and companies came into Sweden for exploration. This in turn affected the exploration expenditure in a positive way illustrated in Fig. 8. Today investments in exploration is at an all-time high, but not without risk!

The Fraser institute is a Canadian institute that carry out research about government actions in areas that deeply affect Canadians' quality of life such as taxation, health care, aboriginal issues, education, economic freedom, 

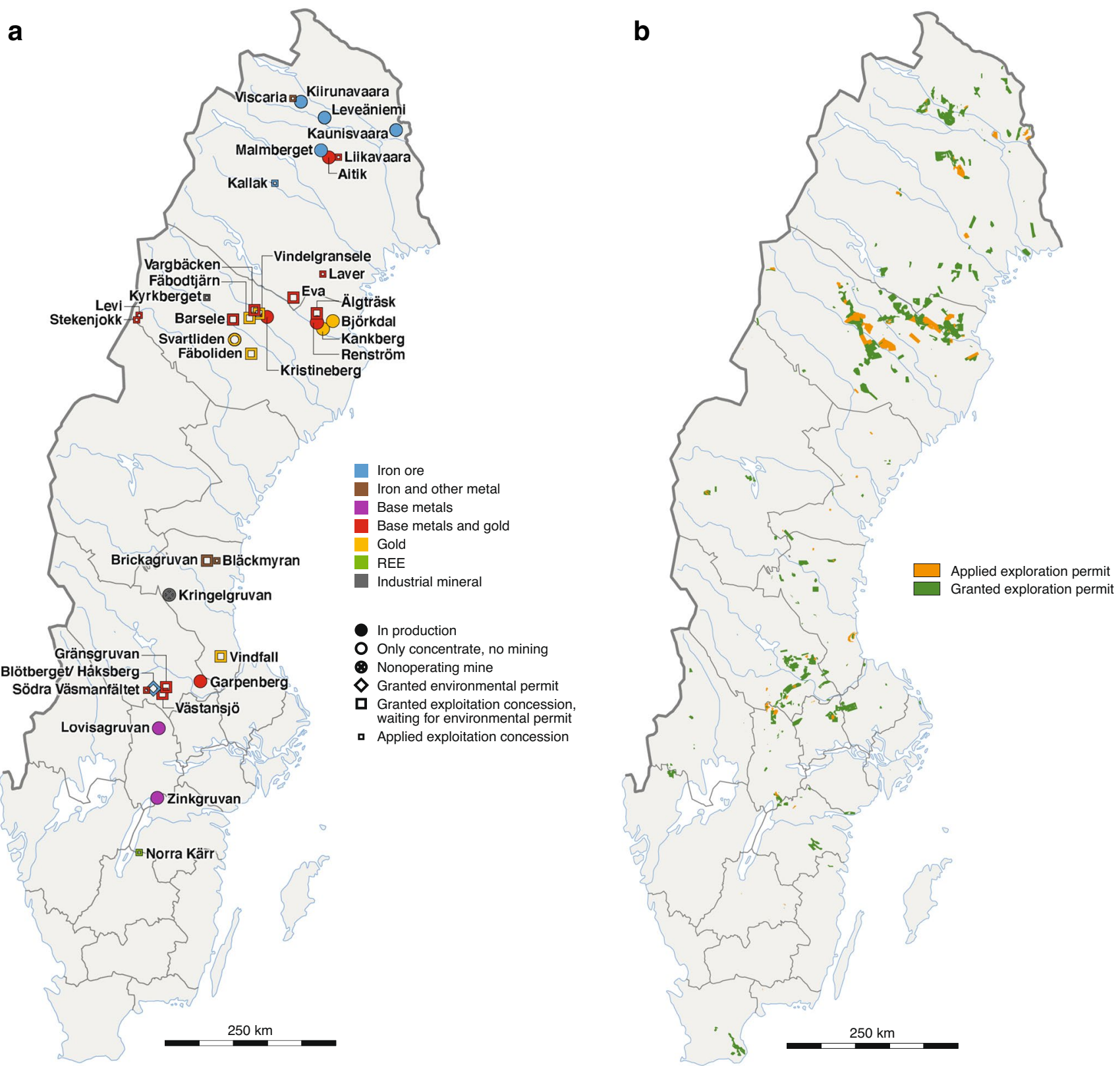

Fig. 9 a) Active mines and exploitation permits in Sweden in 2020. b) valid exploration concessions in Sweden in 2020 (Geological Survey of Sweden 2021)

energy, natural resources, and the environment. For several years they have studied jurisdictions around the world related to the investment climate for natural resources, mining and exploration. In 2020 Sweden was ranked on the $36^{\text {th }}$ place falling from rank 8 in 2016 (Yunis and Aliakbari 2020). In the report investors expressed increased concern over regulatory enforcement, geological database, and regulatory duplication and inconsistencies. In the last decade the permitting process has been extremely slow in Sweden and mining concessions are systematically appealed by both environmental NGOs and authorities like the County administrative boards and the Environmental protection agency. It remains to be seen how this growing frustration among exploration executives will influence the willing to invest in Sweden in the long run.

The review of technical developments within exploration reveals that Swedish scientists and technical developers within companies and the Geological Survey have performed extremely well over the last hundred years or so. Also the leading position of Swedish chemists probably played a major role already before the industrial revolution. Major invention, or further development of technologies, by 
Table 2 Statistics of Swedish exploration permits and exploitation concessions 2000-2020 (https://www.sgu.se/bergsstaten/)

\begin{tabular}{|c|c|c|c|}
\hline Year & $\begin{array}{l}\text { New exploration } \\
\text { permits granted }\end{array}$ & $\begin{array}{l}\text { Valid exploration } \\
\text { permits } 31 / 12\end{array}$ & $\begin{array}{l}\text { Granted exploi- } \\
\text { tation conces- } \\
\text { sions }\end{array}$ \\
\hline 2021 & 85 & 593 & 1 \\
\hline 2020 & 111 & 550 & 0 \\
\hline 2019 & 97 & 586 & 2 \\
\hline 2018 & 152 & 623 & 4 \\
\hline 2017 & 178 & 608 & 6 \\
\hline 2016 & 119 & 604 & 6 \\
\hline 2015 & 122 & 665 & 2 \\
\hline 2014 & 111 & 776 & 3 \\
\hline 2013 & 119 & 959 & 5 \\
\hline 2012 & 182 & 1114 & 6 \\
\hline 2011 & 202 & 1139 & 2 \\
\hline 2010 & 174 & 1197 & 3 \\
\hline 2009 & 208 & 1239 & 4 \\
\hline 2008 & 282 & 1322 & 5 \\
\hline 2007 & 356 & 1235 & 7 \\
\hline 2006 & 377 & 998 & 2 \\
\hline 2005 & 305 & 768 & 1 \\
\hline 2004 & 159 & 630 & 2 \\
\hline 2003 & 183 & $*$ & 2 \\
\hline 2002 & 159 & $*$ & 3 \\
\hline 2001 & 137 & $*$ & 3 \\
\hline 2000 & 192 & $*$ & 7 \\
\hline
\end{tabular}

Source: https://www.sgu.se/bergsstaten/

Swedish companies and scientist have made major contribution within all fields of exploration, not the least geophysical and geochemical exploration methods. Coupled with leading development within drilling technologies this has meant that exploration has been more successful, being able to target deep seated mineralization and resulted in mining productivity that is among the highest in the world, thus giving Swedish mining companies like Boliden and LKAB competitive advantages. Swedish SMEs still preform very well in developing technologies for exploration. The companies Minalyze and Ore Explore are two very good examples.

Acknowledgements The author would like to thank the editor Magnus Ericsson for the encouragement to write this paper. I also would like to acknowledge Prof. Friedrich Wellmer with whom I on many occasions have had interesting discussions especially on the reporting of reserves and the understanding of the role of exploration in upgrading reserves and resources in mines. A fact that is not understood by many decision makers unfortunately! My sincere thanks also to constructive reviews by three anonymous reviewers.

Funding Open access funding provided by Lulea University of Technology.

\section{Declarations}

Conflict of interest The authors declare no competing interests.

Open Access This article is licensed under a Creative Commons Attribution 4.0 International License, which permits use, sharing, adaptation, distribution and reproduction in any medium or format, as long as you give appropriate credit to the original author(s) and the source, provide a link to the Creative Commons licence, and indicate if changes were made. The images or other third party material in this article are included in the article's Creative Commons licence, unless indicated otherwise in a credit line to the material. If material is not included in the article's Creative Commons licence and your intended use is not permitted by statutory regulation or exceeds the permitted use, you will need to obtain permission directly from the copyright holder. To view a copy of this licence, visit http://creativecommons.org/licenses/by/4.0/.

\section{References}

Allen RL, Weihed P, Svenson S-Å (1996a) Setting of Zn-Cu- Au-Ag massive sulfide deposits in the evolution and facies architecture of a $1.9 \mathrm{Ga}$ marine volcanic arc, Skellefte district. Sweden. Economic Geology 91:1022-1053

Allen RL, Lundström I, Ripa M, Simeonov A, Christofferson H (1996b) Facies analysis of a 1.9 Ga., continental margin, backarc, felsic caldera province with diverse $\mathrm{Zn}-\mathrm{Pb}-\mathrm{Ag}-(\mathrm{Cu}-\mathrm{Au})$ sulfide and $\mathrm{Fe}$ oxide deposits, Bergslagen region. Sweden. Economic Geology 91:979-1008

Bauer TE, Skyttä P, Hermansson T, Dehghannejad M, Tavakoli S (2015) The Skellefte District. In 3D, 4D and Predictive Modelling of Major Mineral Belts in Europe. Mineral Resource Reviews, ISSN 2365-0559 Springer Verlag, pp 93-121

Bejgarn T (2012) The Älgträsk intrusion-related $\mathrm{Au}(\mathrm{Cu}, \mathrm{Zn})$ deposit, Skellefte district, northern Sweden: Relationships between ore forming events in the Palaeoproterozoic Jörn intrusive complex. Doctoral thesis / Luleå University of Technology, ISSN 1402-1544

Bergman S, Kübler L Martinsson O (2001) Description of regional geological and geophysical maps of northern Norrbotten County (east of the Caledonian orogen). Sveriges geologiska undersökning $\mathrm{Ba} 56$

Bergman Weihed J, Bergström U, Billström K, Weihed P (1996) Geology and tectonic evolution of the Paleoproterozoic Boliden $\mathrm{Au}-$ $\mathrm{Cu}-\mathrm{As}$ deposit, Skellefte District, northern Sweden. Economic Geology 91:1073-1097

Bergström G, (1913) Försök med Elektrisk Malmletning. SGU Ser. C 259

Bindler R, Karlsson J, Rydberg J (2017) Copper-ore mining in Sweden since the pre-Roman Iron Age: lake sediment evidence of human activities at the Garpenberg ore field since 375 BCE. Journal of Archaeological Science 12:99-108

Geological Survey of Sweden (2004) Bergverksstatistik 2003. Statistics of the Swedish Mining Industry 2003. Per. Publ. 2004:1, ISSN 0283-2038

Geological Survey of Sweden (2021) Bergverksstatistik 2020. Statistics of the Swedish Mining Industry 2020. Per. Publ. 2021:2, ISSN 0283-2038

Burt R (2014) Diamond Core Drills: Their invention, early development, and consequences for mining and quarrying. Mining History Journal, pp 1-21 
Carranza EJM, Sadeghi M (2010) Predictive mapping of prospectivity and quantitative estimation of undiscovered VMS deposits in Skellefte district (Sweden). Ore Geology Reviews 38:219-241

Eklund J (1950a) Malmletningens historia I Skelleftefältet och SGU:s insats. BRAP00152

Eklund J (1950b) Några reflektioner över Västerbottens malmletningshistoria. BRAP00083

Fitterman DV Ed. (1987) Developments and Applications of Modern Airborne Electromagnetic Surveys. USGS Bulletin 1925

Grip E (1961) Geology of the Nickel deposit at Lainijaur in northern Sweden, and a summary of other nickel deposits in Sweden. SGU Ser C 577

Hedström EHL, Tegholm RV (1956) Canadian Patent 528,643, Electromagnetic induction method and apparatus for prospecting. Application filed February 3:1955

Kathol B, Weihed P Eds. (2005) Description of regional geological and geophysical maps of the Skellefte District and surrounding areas. SGU Ser. Ba 57

Koark HJ (1962) Zur Altersstellung und Entstehung der Sulfiderze vom Typus Falun. Geologische Rundschau 52:123-146

Landergren S (1948) On the geochemistry of Swedish Iron ores and Associated Rocks. SGU ser. C496

Lindgren W (1913) Mineral Deposits. New York McGraw-Hill Book Company, Inc.

Lundberg H (1922) Practical experience in Electrical Prospecting. SGU ser. C 319

Lundberg B (1980) Aspects of the geology of the Skellefte field, northern Sweden. GFF 102:156-166

Lundqvist O (2013) Malmletarna. ISBN: 978-91-637-4220-0

Martinsson E (1996) Geochemistry and petrogenesis of the Palaeoproterozoic, nickel-copper bearing Lainijaur intrusion, northern Sweden. GFF 118:97-109

Martinsson O, Billström K, Broman C, Weihed P (2016) Metallogeny of the Northern Norrbotten Ore Province, northern Fennoscandian Shield with emphasis on IOCG and apatite-iron ore deposits. Ore Geology Reviews 78:447-492

Rickard D, Zweifel H (1975) Genesis of Precambrian sulfide ores, Skellefte District, Sweden. Economic Geology 70:255-274

Rinander K (2013) Prospektering i samhällsnyttans tjänst? En problematiserande utredning av lagstiftningen för beslut om undersökningstillstånd, enligt minerallagen (1991:45), och dess verkningar. Lund University, Thesis for exam

SOU 1924:16. Betänkande med förslag till gruvlag

SOU 1980:12: Mineralpolitik : [slutbetänkande]

SOU 1996:152: Gruvorna och Framtiden. Slutbetänkande från Gruvkommitten

SOU 2000:89: Minerallagen, markägarna och miljön

Stephens MB, Ripa M, Lundström I, Persson L, Bergman T, Ahl M, Wahlgren C-H, Persson P-O, Wickström L (2009) Synthesis of the bedrock geology in the Bergslagen region, Fennoscandian Shield, south-central Sweden. SGU Ser, Ba, p 58
Sundberg K, Lundberg H, Eklund J (1923) Electrical Prospecting in Sweden. SGU ser. C 327

Sundblad K (1994) A genetic reinterpretation of the Falun and Åmmeberg ore types, Bergslagen, Sweden. Mineralium Deposita 29:170-179

Tegengren FR, Johansson HE (1924) Sveriges ädlare malmer och bergverk. Sveriges geologiska undersökning $\mathrm{Ca} 17$

Vivallo W, Claesson L-Å (1987) Intra-arc rifting and massive sulphide mineralization in an Early Proterozoic volcanic arc, Skellefte District, northern Sweden. In: Pharaoh, T.C., Beckinsale, R.D., Rickard, D. (Eds.), Geochemistry and Mineralization Of Proterozoic Volcanic Suites. Geological Society, London,Special Publications 33:69-79

Weihed P (1992) Geology and genesis of the Early Proterozoic Tallberg porphyry-type deposit, Skellefte District, northern Sweden. Dissertation A72, University of Göteborg and Chalmers University of Technology, Göteborg

Weihed P, Arndt N, Billström K, Duchesne J-C, Eilu P, Martinsson O, Papunen H, Lahtinen R (2005) Precambrian geodynamics and ore formation: the Fennoscandian Shield. Ore Geology Reviews 27:273-322

Weihed P Ed. (2015) 3D, 4D and Predictive Modelling of Major Mineral Belts in Europe. Springer, ISSN 2365-0559

Yunis J, Aliakbari E (2020) Fraser Institute Annual survey of mining companies 2020

\section{Webpages cited (visited August 2021 and January 2022)}

https:// www. macrotrends. net/ $1333 /$ histo rical-gold-prices-100-year-chart)

http://www.petroleumhistory.org/OilHistory/pages/Diamond/inventor. html

https://www.epiroc.com/en-uk/products/rock-drilling-tools/core-drill ing-tools

https://minalyze.com

https://orexplore.com

https://www.farminproject.eu

https://ec.europa.eu/growth/sectors/raw-materials/policy-and-strategyraw-materials_en

https://ec.europa.eu/growth/sectors/raw-materials/areas-specific-inter est/critical-raw-materials_en

https://www.sgu.se/bergsstaten/

Publisher's note Springer Nature remains neutral with regard to jurisdictional claims in published maps and institutional affiliations. 